\title{
LSD but not lisuride disrupts prepulse inhibition in rats by activating the $5-\mathrm{HT}_{2 \mathrm{~A}}$ receptor
}

\author{
Adam L. Halberstadt • Mark A. Geyer
}

Received: 14 July 2009 / Accepted: 27 October 2009 /Published online: 25 November 2009

(C) The Author(s) 2009. This article is published with open access at Springerlink.com

\begin{abstract}
Rationale Compounds that activate the $5-\mathrm{HT}_{2 \mathrm{~A}}$ receptor, such as lysergic acid diethylamide (LSD), act as hallucinogens in humans. One notable exception is the LSD congener lisuride, which does not have hallucinogenic effects in humans even though it is a potent $5-\mathrm{HT}_{2 \mathrm{~A}}$ agonist. LSD and other hallucinogens have been shown to disrupt prepulse inhibition (PPI), an operational measure of sensorimotor gating, by activating $5-\mathrm{HT}_{2 \mathrm{~A}}$ receptors in rats. Objective We tested whether lisuride disrupts PPI in male Sprague-Dawley rats. Experiments were also conducted to identify the mechanism(s) responsible for the effect of lisuride on PPI and to compare the effects of lisuride to those of LSD.

Results Confirming a previous report, LSD $(0.05,0.1$, and $0.2 \mathrm{mg} / \mathrm{kg}$, s.c.) reduced PPI, and the effect of LSD was blocked by pretreatment with the selective $5-\mathrm{HT}_{2 \mathrm{~A}}$ antagonist MDL 11,939. Administration of lisuride (0.0375, 0.075 , and $0.15 \mathrm{mg} / \mathrm{kg}$, s.c.) also reduced PPI. However, the PPI disruption induced by lisuride $(0.075 \mathrm{mg} / \mathrm{kg})$ was not blocked by pretreatment with MDL 11,939 or the selective $5-\mathrm{HT}_{1 \mathrm{~A}}$ antagonist WAY-100635 but was prevented by pretreatment with the selective dopamine $\mathrm{D}_{2} / \mathrm{D}_{3}$ receptor antagonist raclopride $(0.1 \mathrm{mg} / \mathrm{kg}$, s.c).

Conclusions The effect of LSD on PPI is mediated by the $5-\mathrm{HT}_{2 \mathrm{~A}}$ receptor, whereas activation of the $5-\mathrm{HT}_{2 \mathrm{~A}}$ receptor
\end{abstract}

A. L. Halberstadt

Department of Psychiatry, University of California San Diego,

La Jolla, CA 92093, USA

M. A. Geyer $(\bowtie)$

Department of Psychiatry-0804, University of California,

San Diego,

9500 Gilman Drive,

La Jolla, CA 92093-0804, USA

e-mail: mgeyer@ucsd.edu does not appear to contribute to the effect of lisuride on PPI. These findings demonstrate that lisuride and LSD disrupt PPI via distinct receptor mechanisms and provide additional support for the classification of lisuride as a nonhallucinogenic $5-\mathrm{HT}_{2 \mathrm{~A}}$ agonist.

Keywords Hallucinogen · Rats · Prepulse inhibition · 5-HT2A · Lisuride $\cdot$ LSD

Considerable evidence demonstrates that the $5-\mathrm{HT}_{2 \mathrm{~A}}$ receptor, which is coupled to $G_{\mathrm{q} / 11}$ and activates the phosphoinositide (PI) signaling pathway (Nichols and Nichols 2008), is largely responsible for mediating the effects of lysergic acid diethylamide (LSD) and other serotonergic hallucinogens. Phenylalkylamine and indoleamine hallucinogens bind to the 5- $\mathrm{HT}_{2 \mathrm{~A}}$ receptor with high affinity and act as agonists or partial agonists (Glennon 1990). It has been shown that hallucinogenic potency in humans and behavioral activity in laboratory animals are robustly and significantly correlated with $5-\mathrm{HT}_{2 \mathrm{~A}}$ binding affinity (Glennon et al. 1984; Titeler et al. 1988; Sadzot et al. 1989). Studies in rats have consistently found that the behavioral effects of hallucinogens are blocked by the selective 5- $\mathrm{HT}_{2 \mathrm{~A}}$ antagonist M100907 (Schreiber et al. 1994; Sipes and Geyer 1995a; Krebs-Thomson et al. 1998; Vickers et al. 2001). Likewise, the ability of the hallucinogen 2,5-dimethoxy-4-iodoamphetamine (DOI) to induce head twitch response (HTR) and ear scratch and to increase locomotor activity is abolished in $5-\mathrm{HT}_{2 \mathrm{~A}}-/-$ knockout mice (González-Maeso et al. 2007; Halberstadt et al. 2009). The selective $5-\mathrm{HT}_{2}$ antagonist ketanserin blocks the hallucinogenic effects of the indoleamine psilocybin in human subjects (Vollenweider et al. 1998), providing strong support for the link between $5-\mathrm{HT}_{2 \mathrm{~A}}$ receptor activation and 
hallucinogenesis. Such evidence has implications for the involvement of 5- $\mathrm{HT}_{2 \mathrm{~A}}$ receptor activation in the symptoms of schizophrenia and the mechanisms of action of atypical antipsychotic drugs (Geyer and Vollenweider 2008).

Lisuride hydrogen maleate is an isolysergic acid derivative that has been used clinically in the treatment of migraine (Herrmann et al. 1977; Somerville and Herrmann 1978), cluster headache (Raffaelli et al. 1983), acromegaly and hyperprolactinemia (Liuzzi et al. 1978; Verde et al. 1980), and Parkinson's disease (Parkes et al. 1981; Lieberman et al. 1983). The structure and pharmacological activity of lisuride are strikingly similar to that of LSD. Lisuride and LSD bind non-selectively to a variety of serotonergic, dopaminergic, and adrenergic receptors (Leysen 1989; Piercey et al. 1996; Egan et al. 1998; Marona-Lewicka et al. 2002; Millan et al. 2002; Nichols et al. 2002). Furthermore, LSD and lisuride have high affinity for the $5-\mathrm{HT}_{2 \mathrm{~A}}$ receptor, and both compounds act as partial agonists (Egan et al. 1998; Kurrasch-Orbaugh et al. 2003; Cussac et al. 2008). Nonetheless, despite the similar pharmacological properties of lisuride and LSD, lisuride is devoid of hallucinogenic effects when administered to humans at acute doses of up to $400 \mu \mathrm{g}$ (Herrmann et al. 1977; Verde et al. 1980; Raffaelli et al. 1983; Beneš et al. 2006). This lack of effect contrasts with the potent hallucinogenic activity of LSD, which is psychoactive even at doses as low as 20-30 $\mu \mathrm{g}$ (Stoll 1949; Greiner et al. 1958).

Given the fact that lisuride is not hallucinogenic, many studies have compared the effects of LSD and lisuride directly in order to detect neurochemical differences that may explain why the latter drug is inactive. Toward this goal, lisuride has been tested in several animal behavioral paradigms known to be sensitive to the effects of hallucinogens. Jacobs et al. (1977) proposed that the ability of hallucinogens to induce limb flicks and abortive grooming in cats serves as an animal model of hallucinogen effects. However, lisuride also induces limb flicking and abortive grooming (Marini et al. 1981; White et al. 1981), and thus, this model cannot distinguish between LSD and lisuride. Drug discrimination studies have evaluated whether lisuride can evoke a hallucinogen-like discriminative stimulus, an effect known to be mediated by $5-\mathrm{HT}_{2 \mathrm{~A}}$ receptors (Glennon et al. 1984; Fiorella et al. 1995a). There is some disagreement in the literature regarding the degree to which the stimulus effects of LSD, DOI, and 2,5dimethoxy-4-methylamphetamine (DOM) generalize to lisuride, with some studies reporting full substitution of lisuride for those training drugs (White and Appel 1982; Glennon and Hauck 1985; Fiorella et al. 1995b) and other studies reporting only partial substitution (Holohean et al. 1982; Marona-Lewicka et al. 2002); nonetheless, it is clear that at least some similarity exists between the interoceptive stimulus cues evoked by hallucinogens and lisuride. Adams and Geyer (1985) compared the effects of lisuride and LSD on investigatory behavior and patterns of locomotor activity. The locomotor effects produced by lisuride were found to be distinct from those of LSD and closely resembled the effects of the dopamine (DA) agonist apomorphine.

Hallucinogens, including LSD, DOI, and DOM, induce the HTR in rats and mice, an effect that is mediated by activation of $5-\mathrm{HT}_{2 \mathrm{~A}}$ receptors (Schreiber et al. 1995; Vickers et al. 2001; González-Maeso et al. 2007). Notably, despite the fact that lisuride is a $5-\mathrm{HT}_{2 \mathrm{~A}}$ agonist, studies indicate that lisuride does not evoke the HTR (Gerber et al. 1985; González-Maeso et al. 2007). Based on the behavioral inactivity of lisuride in this paradigm, it appears that the HTR has utility as a behavioral screen that can distinguish hallucinogenic versus nonhallucinogenic 5$\mathrm{HT}_{2 \mathrm{~A}}$ agonists. Unfortunately, the usefulness of the HTR as tool to study the effects of hallucinogens is diminished by the fact that the HTR is a behavioral effect that has no human counterpart, and thus, it is unclear how this behavior relates to the subjective effects of hallucinogens. By contrast, prepulse inhibition (PPI) of acoustic startle is a cross-species phenomenon that can be assessed in humans and animals using similar testing procedures. PPI refers to the fact that a weak prestimulus will attenuate the reaction to a subsequent startle-inducing stimulus and serves as an operational measure of sensorimotor gating. Hallucinogens affect PPI in rodents (Sipes and Geyer 1994; Johansson et al. 1995; Ouagazzal et al. 2001) and in humans (Vollenweider et al. 2007). Importantly, it has been shown that the decrease in PPI induced by LSD in rats is mediated by $5-\mathrm{HT}_{2 \mathrm{~A}}$ receptors (Ouagazzal et al. 2001). The present studies were designed to test whether lisuride disrupts PPI in rats. Experiments were also conducted to identify the mechanism(s) responsible for the effect of lisuride on PPI and to compare the effects of lisuride to those of LSD.

\section{Materials and methods}

Animals

Male Sprague-Dawley rats (Harlan Industries, Indianapolis, IN, USA; initial weight $250-275 \mathrm{~g}$ ) were housed in pairs in a temperature- and humidity-controlled vivarium under a 12-h reverse light-dark cycle (lights off at 0700 hours). Food and water were available ad libitum. Animals were acclimatized for approximately 1 week after arrival prior to behavioral testing and maintained in American Association for Accreditation of Laboratory Animal Care-approved facilities that meet all federal and state guidelines. Proce- 
dures were approved by the University of California San Diego institutional animal care and use committee. Principles of laboratory animal care were followed as well as specific laws of the USA.

\section{Apparatus}

Eight startle chambers (SR-LAB system, San Diego Instruments, San Diego, CA) were used to measure startle reactivity (Mansbach et al. 1988). The startle test chambers consist of a sound-attenuated, lighted, and ventilated enclosure holding a clear nonrestrictive cylindrical Plexiglas stabilimeter, $8.2 \mathrm{~cm}$ in diameter. A high-frequency loudspeaker mounted $24 \mathrm{~cm}$ above the Plexiglas cylinder produced all acoustic stimuli. The peak and average amplitudes of the startle response were detected by a piezoelectric accelerometer, digitized, and stored on disk. At the onset of the startling stimulus, 100 1-ms readings were recorded, and the average amplitude was used to determine the rat startle response. A dynamic calibration system was used to ensure comparable stabilimeter sensitivity across test chambers, and sound levels were measured using the $\mathrm{dB}(\mathrm{A})$ scale, as described previously (Mansbach et al. 1988).

\section{Acoustic startle sessions}

Acoustic startle test sessions consisted of startle trials (pulse-alone) and prepulse trials (prepulse+pulse). The pulse-alone trial consisted of a $40-\mathrm{ms} 120-\mathrm{dB}$ pulse of broadband white noise. Prepulse + pulse trials consisted of a 20-ms acoustic prepulse, an 80-ms delay, and then a 40-ms 120-dB startle pulse (100 ms onset-onset). There was an average of $15 \mathrm{~s}$ (range, 9-21 s) between trials. During each inter-trial interval, the movements of the rats were recorded once to measure responding when no stimulus was present (data not shown). Each startle session began with a 5-min acclimation period to a $65-\mathrm{dB}$ broadband noise that was present continuously throughout the session. One week after arrival, animals were tested in a brief baseline startle/ PPI session to create treatment groups matched for levels of startle and PPI.

For experiments with lisuride, the startle test session included three blocks. The first block tested acoustic startle response only and included four each of five different acoustic stimulus intensities: $80,90,100,110$, and $120 \mathrm{~dB}$ (unpublished data). The second block was designed to assess PPI; it contained 12 pulse-alone trials and 30 prepulse + pulse trials [ten prepulses each of 68,71 , and $77 \mathrm{~dB}$ (or 3, 6, and $12 \mathrm{~dB}$ above background)] presented in a pseudo-randomized order. The third block tested the effect of varying the inter-trial interval on PPI (unpublished data); it contained eight pulse-alone trials and 20 prepulse + pulse trials [77 $\mathrm{dB}$ prepulses (12 $\mathrm{dB}$ above background)]. Five inter-trial intervals (onset-onset) were used for the prepulse+pulse trials: $30,60,120,240$, or $2,000 \mathrm{~ms}$. Five pulse-alone trials were presented at the beginning and the end of the test session but were not used in the calculation of PPI values.

For experiments with LSD, the startle test session included only one block. The test session contained 14 pulse-alone trials and 36 prepulse + pulse trials [12 prepulses each of 68,71 , and $77 \mathrm{~dB}$ (or 3, 6, and $12 \mathrm{~dB}$ above background)] presented in a pseudo-randomized order. Five pulse-alone trials were presented at the beginning and the end of the test session but were not used in the calculation of PPI values.

\section{Data analysis}

The amount of PPI was calculated as a percentage score for each prepulse+pulse trial type:\%PPI $=100-\{[$ (startle response for prepulse+pulse trial)/(startle response for pulse-alone trial) $] \times 100\}$. Startle magnitude was calculated as the average response to all of the pulse-alone trials. PPI data were analyzed with two- or three-factor analysis of variance (ANOVA) with pretreatment and/or treatment as between-subjects factors and trial type (prepulse intensity) as a repeated measure. For experiments in which there was no significant interaction between drug and prepulse intensity, PPI data were collapsed across prepulse intensity and the average PPI was used as the main dependent measure. Startle magnitude data were analyzed with one- or two-factor (pretreatment and/or treatment) ANOVA. Posthoc analyses were carried out using Tukey's test. The alpha level was set at 0.05 .

\section{Experimental design}

Animals were placed in the startle chambers $10 \mathrm{~min}$ after treatment with lisuride or $5 \mathrm{~min}$ after treatment with LSD. In experiment 1 , rats $(n=9-10,38$ total) were treated with vehicle, $37.5,75$, or $150 \mu \mathrm{g} / \mathrm{kg}$ lisuride. In experiment 2 , rats $(n=10-12,45$ total) were treated with MDL 11,939 (vehicle or $0.3 \mathrm{mg} / \mathrm{kg}$ ) $20 \mathrm{~min}$ before administration of lisuride (vehicle or $75 \mu \mathrm{g} / \mathrm{kg}$ ). In experiment 3 , rats $(n=11-$ 12, 46 total) were treated with raclopride (vehicle or $0.1 \mathrm{mg} / \mathrm{kg}$ ) $10 \mathrm{~min}$ before administration of lisuride (vehicle or $75 \mu \mathrm{g} / \mathrm{kg})$. In experiment 4 , rats $(n=12-13,50$ total $)$ were treated with WAY-100635 (vehicle or $1.0 \mathrm{mg} / \mathrm{kg}$ ) $20 \mathrm{~min}$ before administration of lisuride (vehicle or $75 \mu \mathrm{g} / \mathrm{kg}$ ). In experiment 5 , rats $(n=11-12,47$ total $)$ were treated with vehicle, 50,100, or $200 \mu \mathrm{g} / \mathrm{kg}$ LSD. In experiment 6 , rats ( $n=11-12,46$ total) were treated with MDL 11,939 (vehicle or $0.3 \mathrm{mg} / \mathrm{kg}$ ) $25 \mathrm{~min}$ before administration of LSD (vehicle or $100 \mu \mathrm{g} / \mathrm{kg}$ ). 


\section{Drugs}

Drugs used were as follows: lisuride hydrogen maleate (purity 98.9\%, IVAX Pharmaceuticals, Opava, Czech Republic); $S$-(-)-raclopride tartrate, $N$-[2-[4-(2-methoxyphenyl)-1-piperazinyl] ethyl]- $N$-2-pyridinylcyclohexanecarboxamide maleate (WAY-100635; Sigma-Aldrich, St. Louis, MO, USA); $\alpha$-phenyl-1-(2-phenylethyl)-4-piperidinemethanol (MDL 11,939; Tocris Bioscience, Ellisville, MO, USA); and (+)-lysergic acid diethylamide tartrate (LSD) (National Institute on Drug Abuse, Rockville, MD, USA). Drug doses are expressed as the salt form of the drug, with the exception of MDL 11,939, which refers to the freebase. Lisuride and LSD were dissolved in nitrogen-purged isotonic saline. MDL 11,939 was dissolved in saline (pH 5.0) containing $0.75 \%$ Tween 80 . All other drugs were dissolved in isotonic saline. All drugs were administered subcutaneously in the nape of the neck in a volume of $1 \mathrm{ml} / \mathrm{kg}$.

\section{Results}

\section{Experiment 1: lisuride dose response}

As shown in Fig. 1, administration of lisuride significantly reduced PPI $[F(3,34)=12.74, p<0.0001]$. Post hoc comparisons confirmed that all three doses of lisuride decreased PPI $(p<0.05,0.01)$. There was a significant main effect of prepulse intensity $[F(2,68)=7.82, p=0.0009$; this effect was observed in all subsequent experiments], and there was a significant interaction between lisuride and prepulse intensity $[F(6,68)=3.11, p<0.01]$. Inspection of the data revealed significant effects of $37.5 \mu \mathrm{g} / \mathrm{kg}$ lisuride only for the 68 - and 71-dB prepulse intensities ( 3 and $6 \mathrm{~dB}$ over background; $p<$ $0.05,0.01)$, whereas $75 \mu \mathrm{g} / \mathrm{kg}$ lisuride significantly decreased
PPI only at the 71- and 77-dB prepulse intensities $(p<0.01)$. Administration of $75 \mu \mathrm{g} / \mathrm{kg}$ lisuride decreased PPI at the 68$\mathrm{dB}$ prepulse intensity, and this effect approached but did not reach significance $(p<0.1)$. The highest dose of lisuride tested $(150 \mu \mathrm{g} / \mathrm{kg})$ decreased PPI at all three prepulse intensities $(p<0.01)$. There was an effect of lisuride on startle amplitude during block $2[F(3,34)=4.16, p<0.02]$. Post hoc comparisons revealed that $37.5 \mu \mathrm{g} / \mathrm{kg}$ lisuride significantly decreased startle magnitude $(p<0.05$; Table 1$)$. To confirm that the effect of lisuride on PPI is independent of changes in startle, we examined the effect of lisuride on PPI in subgroups of rats that were matched for block 2 startle magnitude (mean $\pm \mathrm{SEM}=320.32 \pm 24.68,261.72 \pm 17.98,257.28 \pm 14.68$, and 299.88 \pm 21.23 ). Although lisuride had no effect on startle magnitude in those animals $[F(3,16)=2.32, p<0.2 \mathrm{NS}]$, PPI was still significantly reduced $[F(3,16)=4.97, p<0.02]$.

Experiment 2: lisuride versus the 5- $\mathrm{HT}_{2 \mathrm{~A}}$ antagonist $\mathrm{MDL}$ 11,939

As expected, $75 \mu \mathrm{g} / \mathrm{kg}$ lisuride produced a significant decrease in PPI $[F(1,41)=34.62, p<0.0001]$. However, there was no significant interaction between pretreatment and treatment, indicating that the effect of lisuride was not blocked by pretreatment with $0.3 \mathrm{mg} / \mathrm{kg}$ MDL 11,939 (Fig. 2a). The dose of MDL 11,939 used was previously demonstrated to block $5-\mathrm{HT}_{2 \mathrm{~A}}$ receptor-mediated behavioral effects completely (Halberstadt et al. 2008). Pretreatment with MDL 11,939 had no effect on PPI. Neither pretreatment nor treatment significantly affected startle magnitude (Table 1).

Experiment 3: lisuride versus the $\mathrm{D}_{2 / 3}$ antagonist raclopride

Administration of lisuride produced a significant decrease in PPI $[F(1,42)=14.39, p=0.0005]$. There was a significant
Fig. 1 Left panel Effects of lisuride $(0.0375,0.075$, and $0.15 \mathrm{mg} / \mathrm{kg}$, s.c.) on prepulse inhibition. Right panel Effects of lisuride averaged across the three prepulse intensities. Values represent mean \pm SEM for each group. Drug doses are in milligram per kilogram. ${ }^{*} p<0.05$, $* * p<0.01$, significantly different from vehicle control

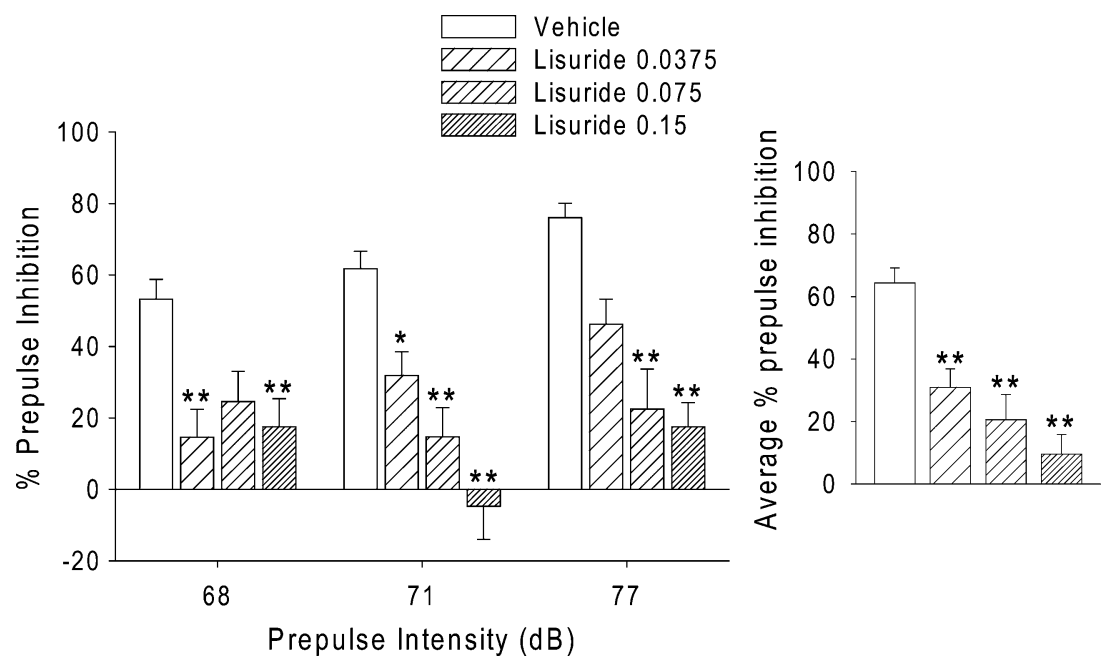


Table 1 Effect of drug treatment on startle magnitude

\begin{tabular}{|c|c|c|c|}
\hline Pretreatment $(\mathrm{mg} / \mathrm{kg})$ & Treatment $(\mathrm{mg} / \mathrm{kg})$ & $n$ & Startle magnitude (mean \pm SEM) \\
\hline & Vehicle & 9 & $457.95 \pm 67.80$ \\
\hline & Lisuride 0.0375 & 10 & $221.68 \pm 45.98^{*}$ \\
\hline & Lisuride 0.075 & 10 & $247.43 \pm 36.41$ \\
\hline & Lisuride 0.15 & 9 & $389.55 \pm 69.80$ \\
\hline Vehicle & Vehicle & 11 & $275.30 \pm 36.60$ \\
\hline MDL 11,939 0.3 & Vehicle & 12 & $300.94 \pm 44.15$ \\
\hline Vehicle & Lisuride 0.075 & 10 & $178.96 \pm 30.63$ \\
\hline MDL 11,939 0.3 & Lisuride 0.075 & 12 & $202.83 \pm 29.89$ \\
\hline Vehicle & Vehicle & 12 & $437.63 \pm 83.94$ \\
\hline Raclopride 0.1 & Vehicle & 11 & $260.07 \pm 29.69$ \\
\hline Vehicle & Lisuride 0.075 & 11 & $262.48 \pm 53.36$ \\
\hline Raclopride 0.1 & Lisuride 0.075 & 12 & $218.04 \pm 43.22 *$ \\
\hline Vehicle & Vehicle & 12 & $397.60 \pm 86.39$ \\
\hline WAY 1006351.0 & Vehicle & 13 & $300.35 \pm 56.09$ \\
\hline Vehicle & Lisuride 0.075 & 12 & $327.423 \pm 46.89$ \\
\hline \multirow[t]{5}{*}{ WAY 1006351.0} & Lisuride 0.075 & 13 & $103.69 \pm 12.20^{* *}$ \\
\hline & Vehicle & 12 & $543.67 \pm 110.96$ \\
\hline & LSD 0.05 & 12 & $320.74 \pm 64.62$ \\
\hline & LSD 0.1 & 12 & $287.22 \pm 65.86$ \\
\hline & LSD 0.2 & 11 & $252.93 \pm 40.19$ \\
\hline Vehicle & Vehicle & 11 & $261.74 \pm 34.75$ \\
\hline MDL 11,939 0.3 & Vehicle & 12 & $224.07 \pm 26.19$ \\
\hline Vehicle & LSD 0.1 & 12 & $248.88 \pm 22.57$ \\
\hline MDL 11,939 0.3 & LSD 0.1 & 11 & $262.89 \pm 40.53$ \\
\hline
\end{tabular}

${ }^{*} p<0.05,{ }^{* *} p<0.01$ versus vehicle or vehicle-vehicle control interaction of pretreatment and treatment $[F(1,42)=6.18, p<$ 0.02]. As shown in Fig. $2 \mathrm{~b}, 0.1 \mathrm{mg} / \mathrm{kg}$ raclopride blocked the reduction of PPI induced by $75 \mu \mathrm{g} / \mathrm{kg}$ lisuride $(p<0.05)$. There was a trend toward a main effect of pretreatment on PPI $[F(1,42)=2.90, p<0.1]$, but this effect was not confirmed by post hoc analysis. There were also trends toward main effects of pretreatment $[F(1,42)=3.74, p<0.06]$ and treatment $[F(1,42)=3.58, p<0.07]$ on startle amplitude during block 2 (Table 1). However, there was no interaction between treatment and pretreatment for startle amplitude. To confirm that the ability of raclopride to block the lisurideinduced decrease in PPI is independent of changes in startle, we examined the effect of raclopride and lisuride on PPI in subgroups of rats that were matched for block 2 startle magnitude. Startle magnitude in that subset of animals was not affected by either pretreatment $[F(1,20)=0.00, \mathrm{NS}]$ or treatment $[F(1,20)=0.63$, NS $]$, and there was no pretreatment $\times$ treatment interaction $[F(1,20)=1.39$, NS $]$. Nonetheless, for PPI, there was still a significant effect of treatment $[F(1,20)=5.76, p<0.03]$, and a significant interaction between pretreatment and treatment $[F(1,20)=6.68, p<0.02]$.
Experiment 4: lisuride versus the $5-\mathrm{HT}_{1 \mathrm{~A}}$ antagonist WAY-100635

There was a significant decrease in PPI after treatment with $75 \mu \mathrm{g} / \mathrm{kg}$ lisuride $[F(1,46)=22.75, p<0.0001]$, but there was no significant interaction between pretreatment and treatment, indicating that the effect of lisuride was not blocked by pretreatment with $1.0 \mathrm{mg} / \mathrm{kg}$ WAY100635 (Fig. 2c). There were main effects of pretreatment $[F(1,46)=8.37, p<0.006]$ and treatment $[F(1,46)=5.78, p<$ $0.03]$ on startle amplitude, but no interaction between pretreatment and treatment. Post hoc comparisons demonstrated that startle amplitude was only significantly reduced in the WAY-100635-lisuride treatment group (Table 1).

Experiment 5: LSD dose response

Confirming a previous report (Ouagazzal et al. 2001), there was a significant main effect of LSD on PPI $[F(3,43)=6.60$, $p=0.0009]$. There was no treatment $\times$ intensity interaction. 

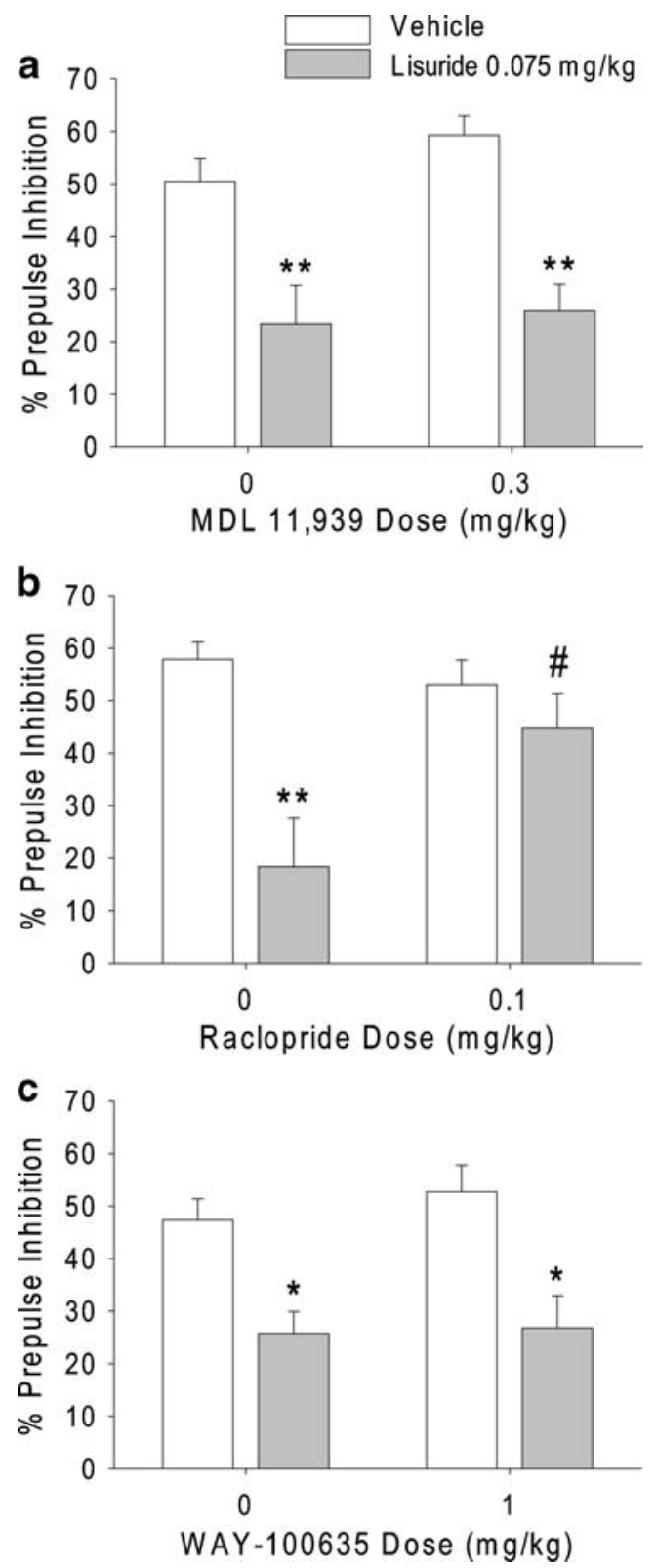

Fig. 2 Effects of a the selective 5-HT $2 \mathrm{~A}$ antagonist MDL 11,939, b the $\mathrm{D}_{2} / \mathrm{D}_{3}$ antagonist raclopride, and $\mathbf{c}$ the 5-HT1A antagonist WAY100635 on the disruption of PPI induced by lisuride. Values represent mean \pm SEM for each group. ${ }^{*} p<0.05,{ }^{* *} p<0.01$, significantly different from vehicle control, and ${ }^{\#} p<0.05$, significantly different from lisuride-treated animals

Figure 3 shows that the two highest doses of LSD (100 and $200 \mu \mathrm{g} / \mathrm{kg})$ significantly decreased PPI $(p<0.01)$. There was an overall effect of LSD on startle amplitude $[F(3,43)=$ 2.99, $p<0.05]$. Tukey's test revealed that 100 and $200 \mu \mathrm{g} / \mathrm{kg}$ LSD induced a nonsignificant decrease in startle magnitude $(p<0.1)$. However, when subgroups of rats were matched for startle magnitude $[F(3,20)=0.57, \mathrm{NS}]$, LSD was still capable of decreasing PPI $[\mathrm{F}(3,20)=3.60$, $p<0.04]$.
Experiment 6: $\mathrm{LSD}$ versus the 5- $\mathrm{HT}_{2 \mathrm{~A}}$ antagonist $\mathrm{MDL}$ 11,939

There was an interaction between pretreatment and treatment $[F(1,42)=4.23, p<0.05]$. Figure 4 shows that the disruption of PPI produced by $100 \mu \mathrm{g} / \mathrm{kg}$ LSD was significantly attenuated by $0.3 \mathrm{mg} / \mathrm{kg}$ MDL $11,939(p<$ $0.01)$. As expected, there was a main effect of treatment $[F(1,42)=12.86, p=0.0009]$. Post hoc analysis revealed that $100 \mu \mathrm{g} / \mathrm{kg}$ LSD significantly decreased PPI $(p<0.01)$. There was also a main effect of pretreatment $[F(1,42)=$ $10.05, p<0.003]$, but this effect was not confirmed by post hoc analysis. There was no significant effect of either pretreatment or treatment on startle magnitude (Table 1).

\section{Discussion}

The present study demonstrated that lisuride produced a dose-dependent disruption of PPI in rats. The selective dopamine (DA) $\mathrm{D}_{2} / \mathrm{D}_{3}$ receptor antagonist raclopride blocked the lisuride-induced PPI disruption. Conversely, the selective $5-\mathrm{HT}_{2 \mathrm{~A}}$ antagonist MDL 11,939 did not prevent the disruption of PPI by lisuride. Although lisuride is a potent and highly efficacious agonist at the $5-\mathrm{HT}_{1 \mathrm{~A}}$ receptor (Marona-Lewicka et al. 2002) and activation of 5$\mathrm{HT}_{1 \mathrm{~A}}$ receptors has previously been shown to disrupt PPI in rats (Sipes and Geyer 1995b), we were unable to block the effect of lisuride with the selective $5-\mathrm{HT}_{1 \mathrm{~A}}$ antagonist WAY-100635. These results strongly indicate that the effect of lisuride on PPI is mediated by $\mathrm{D}_{2} / \mathrm{D}_{3}$ receptors and not by $5-\mathrm{HT}_{2 \mathrm{~A}}$ or $5-\mathrm{HT}_{1 \mathrm{~A}}$ receptors. We also tested the effect of LSD and found that LSD disrupts PPI, confirming a previous report (Ouagazzal et al. 2001). Ouagazzal et al. (2001) also reported that the ability of LSD to reduce PPI is blocked by pretreatment with the selective $5-\mathrm{HT}_{2 \mathrm{~A}}$ antagonist M100907 but is unaffected by pretreatment with the $\mathrm{D}_{2} / \mathrm{D}_{3}$ antagonist haloperidol. Likewise, we found that MDL 11,939 blocked LSD-induced disruption of PPI. Thus, although LSD and lisuride both disrupt PPI, they do so by different receptor mechanisms.

The finding that lisuride disrupts PPI by activating $\mathrm{D}_{2} /$ $\mathrm{D}_{3}$ receptors is consistent with previous evidence demonstrating that lisuride is a dopaminergic drug. Lisuride binds to $\mathrm{D}_{2}$ and $\mathrm{D}_{3}$ receptors with high affinity $\left(K_{\mathrm{i}}\right.$ values of 0.3 and $1.7 \mathrm{nM}$, respectively; Piercey et al. 1996) and acts as a partial agonist at recombinant $D_{2}$ and $D_{3}$ receptors (Newman-Tancredi et al. 2002a). Autoradiography has confirmed that $\left[{ }^{3} \mathrm{H}\right]$ lisuride binds to $\mathrm{D}_{2}$-like receptors in the striatum, nucleus accumbens, and olfactory tubercle in rat brain (Kimura et al. 1991). Lisuride has also been shown to directly inhibit the firing of A10 dopaminergic neurons in the ventral tegmental area (White and Wang 1983, 1984), 
Fig. 3 Left panel Effects of LSD $(0.05,0.1$, and $0.2 \mathrm{mg} / \mathrm{kg}$, s.c.) on prepulse inhibition. Right panel Effects of LSD averaged across the three prepulse intensities. Values represent mean \pm SEM for each group. Drug doses are in milligram per kilogram. ${ }^{*} p<0.05$, $* * p<0.01$, significantly different from vehicle control

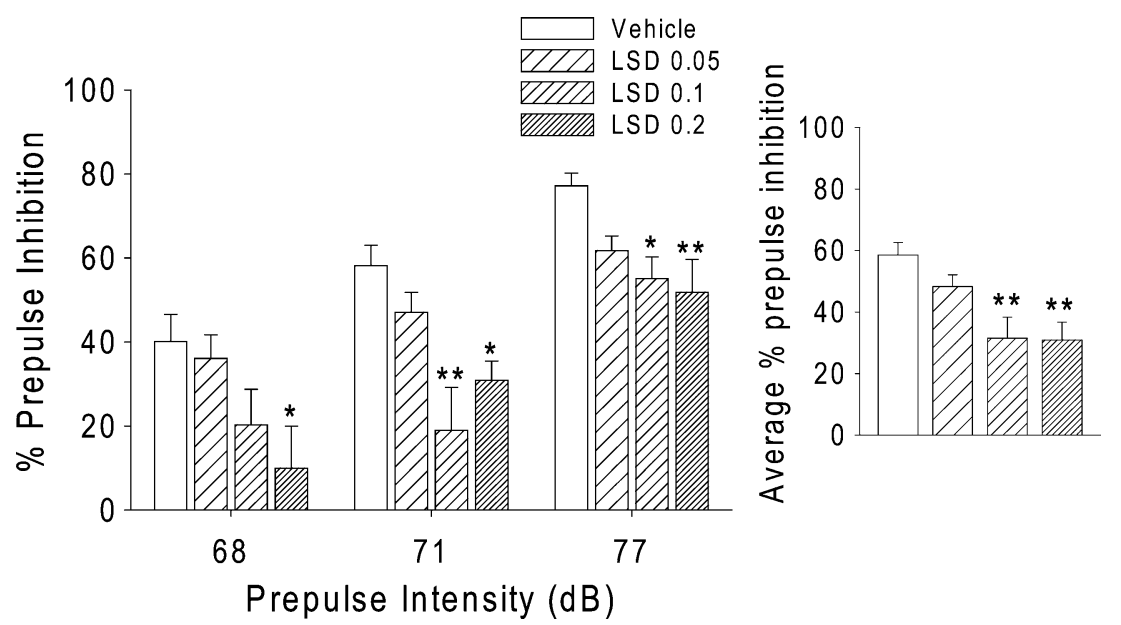

indicating that it activates DA autoreceptors. Behavioral studies also demonstrate that lisuride has DA agonist activity. For example, lisuride induces contralateral turning in rats with unilateral 6-hydroxydopamine-induced lesions of the nigrostriatal DA pathway (Pieri et al. 1978), an effect that is consistent with direct activation of postsynaptic DA receptors. The effects of lisuride on locomotor activity are also similar to those of the DA agonist apomorphine and different from those of LSD (Adams and Geyer 1985). Furthermore, in drug discrimination studies, lisuride produces symmetrical generalization with the $\mathrm{D}_{2}$ agonists apomorphine and terguride (Holohean et al. 1982; Kimura et al. 1991; Yamaguchi et al. 1991).

LSD, like lisuride, is a dopaminergic agent. LSD binds to $D_{1}, D_{2}, D_{3}, D_{4}$, and $D_{5}$ receptors (Nichols et al. 2002) and has been reported to act as a partial agonist at $\mathrm{D}_{1}$ receptors (Watts et al. 1995). Although we did not test whether raclopride blocks the effect of LSD on PPI, it was previously reported that haloperidol fails to attenuate the

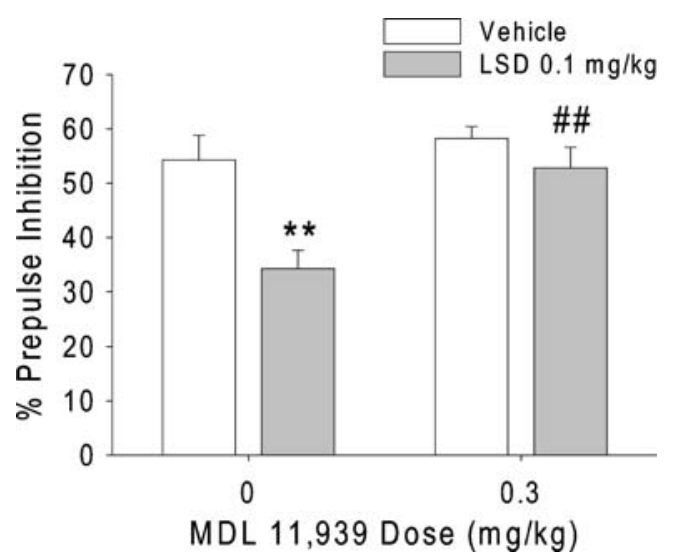

Fig. 4 Effect of the selective 5-HT $\mathrm{H}_{2 \mathrm{~A}}$ antagonist MDL 11,939 on the disruption of PPI induced by LSD. Values represent mean \pm SEM for each group. ${ }^{* *} p<0.01$, significantly different from vehicle control, and ${ }^{\# \#} p<0.01$, significantly different from LSD-treated animals
PPI-disruptive effect of LSD (Ouagazzal et al. 2001). Drug discrimination studies have also shown that dopaminergic activity does not contribute to the behavioral effects of LSD (Kuhn et al. 1978). However, recent evidence indicates that the dopaminergic effects of LSD may be time-dependent. Studies that have trained rats to discriminate LSD have typically used pretreatment times ranging from 15 to $30 \mathrm{~min}$ and have reliably shown that $5-\mathrm{HT}_{2 \mathrm{~A}}$ antagonists block LSD-induced stimulus control. When a longer pretreatment time of $90 \mathrm{~min}$ is used, however, the resulting LSD cue is mediated by DA receptors rather than by 5 $\mathrm{HT}_{2 \mathrm{~A}}$ receptors (Marona-Lewicka et al. 2009). This finding raises the possibility that LSD may disrupt PPI via a dopaminergic mechanism if long pretreatment times are used.

As was noted earlier, lisuride has been tested in numerous clinical trials, but it has never been shown that the drug can produce hallucinogenic effects in normal individuals. Parkinsonism patients treated chronically with high daily doses of lisuride have been reported to experience CNS side effects, including confusion and hallucinations (Schachter et al. 1979; Lieberman et al. 1981; Gopinathan et al. 1981; Vaamonde et al. 1991). However, chronic administration of equivalent doses of lisuride to non-parkinsonian patients does not produce any significant CNS sequelae (Verde et al. 1980; Gillin et al. 1994; Schmidt et al. 2002). The DA agonist bromocriptine is also known to elicit hallucinations in Parkinsonism patients, an effect that is not observed when the drug is used to treat endocrine disorders (Vance et al. 1984). It is therefore likely that the ability of lisuride to induce hallucinations in Parkinsonism patients is due to its potent dopaminergic activity combined with underlying neuropathology, rather than to a LSD-like effect (Vaamonde et al. 1991).

Although both LSD and lisuride produce PPI disruption, we found that the receptors involved in the effects of these 
two drugs are distinct. Despite the fact that lisuride is a 5$\mathrm{HT}_{2 \mathrm{~A}}$ agonist, it did not disrupt PPI via a mechanism involving $5-\mathrm{HT}_{2 \mathrm{~A}}$ receptors, indicating that PPI can be used to differentiate hallucinogenic and non-hallucinogenic 5$\mathrm{HT}_{2 \mathrm{~A}}$ agonists. This is an important finding because PPI is a cross-species behavioral paradigm that is altered by hallucinogens in animals and in humans. Tests with HTR have also demonstrated that there are behavioral differences between LSD and lisuride, but unfortunately HTR is not analogous to any behavior induced by hallucinogens in humans. The finding that the $5-\mathrm{HT}_{2 \mathrm{~A}}$ receptor is not involved in the effect of lisuride on PPI provides additional support for the classification of lisuride as a nonhallucinogenic $5-\mathrm{HT}_{2 \mathrm{~A}}$ agonist.

Several explanations have been proposed to account for the fact lisuride is not hallucinogenic. There has been speculation that the potent interaction of lisuride with 5$\mathrm{HT}_{1 \mathrm{~A}}$ receptors may be acting to functionally antagonize the response to $5-\mathrm{HT}_{2 \mathrm{~A}}$ receptor activation (Marona-Lewicka et al. 2002), but recent findings do not support this hypothesis (González-Maeso et al. 2007). Data have also been published, indicating that LSD is a $5-\mathrm{HT}_{2 \mathrm{C}}$ agonist, whereas lisuride acts as a $5-\mathrm{HT}_{2 \mathrm{C}}$ antagonist (Burris et al. 1991; Fitzgerald et al. 1999), and it has been proposed that lisuride may be non-hallucinogenic because it fails to activate the 5- $\mathrm{HT}_{2 \mathrm{C}}$ receptor (Burris et al. 1991; Sanders-Bush 1994). However, other studies have demonstrated that lisuride acts as an agonist at the $5-\mathrm{HT}_{2 \mathrm{C}}$ receptor (Egan et al. 1998, 2000; Newman-Tancredi et al. 2002b; Marona-Lewicka et al. 2002; Cussac et al. 2008). It is therefore unlikely that differences between the effects of LSD and lisuride on $5-\mathrm{HT}_{2 \mathrm{C}}$ receptors account for the inactivity of the latter drug.

González-Maeso et al. (2007) suggested that differences in the behavioral effects of LSD and lisuride may be due to agonist-directed trafficking of $5-\mathrm{HT}_{2 \mathrm{~A}}$ responses. Agonistdirected trafficking, or functional selectivity, refers to the phenomenon where receptors can couple independently to multiple effector mechanisms, and agonists may selectively activate a subset of the signaling pathways (Kenakin 1995). Both LSD and lisuride activate $\mathrm{G}_{\mathrm{q} / 11}$ signaling via the 5$\mathrm{HT}_{2 \mathrm{~A}}$ receptor. Conversely, LSD but not lisuride increases the cortical expression of egr-1 and egr-2 by activating pertussis toxin-sensitive $\mathrm{G}_{\mathrm{i} / \mathrm{o}}$ proteins and $\mathrm{Src}$ (González-Maeso et al. 2007). These workers also found that lisuride does not induce the HTR in mice and proposed that LSD and other hallucinogens are capable of inducing this behavioral response because they activate specific signaling mechanisms that are not recruited by lisuride.

Two key findings in the literature, however, do not support the agonist-directed trafficking hypothesis. First, although lisuride does not induce the HTR in rats (Gerber et al. 1985) or mice (González-Maeso et al. 2007), it does evoke the behavior in the least shrew (Cryptotis parva; Darmani et al. 1994). Thus, lisuride can induce head twitch under certain conditions (administration to a species that is highly sensitive to the behavioral effects of $5-\mathrm{HT}_{2 \mathrm{~A}}$ agonists). Second, the ability of DOI to induce the HTR is markedly attenuated in $\mathrm{G}_{\mathrm{q}}-/-$ knockout mice (Garcia et al. 2007), indicating that the $\mathrm{G}_{\mathrm{q} / 11}$ pathway is involved in mediating the HTR to $5-\mathrm{HT}_{2 \mathrm{~A}}$ activation. The latter finding is significant because both LSD and lisuride activate the $\mathrm{G}_{\mathrm{q} / 11}$ pathway.

Recently, Cussac et al. (2008) compared the efficacies of LSD and lisuride for $\mathrm{G}_{\mathrm{q} / 11}$ activation and calcium mobilization in $\mathrm{CHO}$ cells transfected with the human $5-\mathrm{HT}_{2 \mathrm{~A}}$ receptor. LSD activated both pathways with high efficacy, whereas lisuride was less efficacious, having only $57 \%$ of the efficacy of LSD. Based on the fact that $\mathrm{G}_{\mathrm{q}}$ plays a role in transducing the behavioral effects of $5-\mathrm{HT}_{2 \mathrm{~A}}$ receptor activation (Garcia et al. 2007), these workers proposed that lisuride may have insufficient efficacy at the $5-\mathrm{HT}_{2 \mathrm{~A}}$ receptor to induce HTR and other behavioral effects. Thus, lisuride may fail to recruit $\mathrm{G}_{\mathrm{i} / \mathrm{o}}$ not because of agonistdirected receptor trafficking but rather because it has very low intrinsic efficacy at the $5-\mathrm{HT}_{2 \mathrm{~A}}$ receptor.

Results obtained using the drug discrimination paradigm are consistent with the hypothesis that lisuride fails to induce hallucinogenic effects because it has relatively weak efficacy at the $5-\mathrm{HT}_{2 \mathrm{~A}}$ receptor in vivo. Even though the DOM stimulus completely generalizes to lisuride (Glennon and Hauck 1985; Fiorella et al. 1995b), DOM-induced stimulus control is attenuated when the training drug is coadministered with lisuride (Glennon 1991). Thus, the effects of lisuride in the drug discrimination paradigm are consistent with the behavior of a partial agonist. As would be expected for a partial agonist, lisuride is active when administered alone but acts as an antagonist when administered in combination with a more efficacious agonist (e.g., DOM). Indeed, using formation of $\left[{ }^{3} \mathrm{H}\right]$ inositol phosphates as a measure of $5-\mathrm{HT}_{2 \mathrm{~A}}$ agonist efficacy, lisuride is only $20 \%$ as efficacious as DOM (Rabin et al. 2002).

Regardless of the underlying mechanism, there is substantial evidence that LSD and lisuride evoke distinct neurochemical and behavioral effects. It has been demonstrated that lisuride fails to mimic fully the effects of LSD on the activity of neurons in prefrontal cortex (Arvanov et al. 1999) and facial nucleus (McCall and Aghajanian 1980). Furthermore, there are marked differences in the effects of lisuride and LSD on gene expression (González-Maeso et al. 2003, 2007). Studies with head twitch indicate that this behavior is sensitive to LSD but not lisuride, at least in certain species. The present investigation extends those previous findings by demonstrating that different receptor mechanisms are responsible for the effects of LSD and lisuride on PPI. Further work is needed to clarify how these findings relate to the effects of LSD and lisuride in humans. 
Nevertheless, this study demonstrates that PPI can serve as a useful tool to compare hallucinogenic and nonhallucinogenic $5-\mathrm{HT}_{2 \mathrm{~A}}$ agonists.

Acknowledgments This work was supported by National Institute on Drug Abuse Awards DA002925 and DA025412 and the Veterans Affairs VISN 22 Mental Illness Research, Education, and Clinical Center. M.A. Geyer holds an equity interest in San Diego Instruments, Inc.

Open Access This article is distributed under the terms of the Creative Commons Attribution Noncommercial License which permits any noncommercial use, distribution, and reproduction in any medium, provided the original author(s) and source are credited.

\section{References}

Adams LM, Geyer MA (1985) Patterns of exploration in rats distinguish lisuride from lysergic acid diethylamide. Pharmacol Biochem Behav 23:461-468

Arvanov VL, Liang X, Russo A, Wang R (1999) LSD and DOB: interaction with $5-\mathrm{HT}_{2 \mathrm{~A}}$ receptors to inhibit NMDA receptormediated transmission in the rat prefrontal cortex. Eur J NeuroSci 11:3064-3072

Beneš H, Deissler A, Rodenbeck A, Engfer A, Kohnen R (2006) Lisuride treatment of Restless Legs Syndrome: first studies with monotherapy in de novo patients and in combination with levodopa in advanced disease. J Neural Transm 113:87-92

Burris KD, Breeding M, Sanders-Bush E (1991) (+)Lysergic acid diethylamide, but not its nonhallucinogenic congeners, is a potent serotonin 5-HT $1 \mathrm{C}$ receptor agonist. J Pharmacol Exp Ther 258:891-896

Cussac D, Boutet-Robinet E, Ailhaud MC, Newman-Tancredi A, Martel JC, Danty N, Rauly-Lestienne I (2008) Agonist-directed trafficking of signaling at serotonin $5-\mathrm{HT}_{2 \mathrm{~A}}, 5-\mathrm{HT}_{2 \mathrm{~B}}$ and $5-\mathrm{HT}_{2 \mathrm{C}-}$ vsv receptors mediated $\mathrm{Gq} / 11$ activation and calcium mobilisation in CHO cells. Eur J Pharmacol 594:32-38

Darmani NA, Mock OB, Towns LC, Gerdes CF (1994) The head twitch response in the least shrew (Cryptotis parva) is a $5-\mathrm{HT}_{2}-$ and not a 5-HT $1 \mathrm{C}-$-mediated phenomenon. Pharmacol Biochem Behav 48:383-396

Egan CT, Herrick-Davis K, Miller K, Glennon RA, Teitler M (1998) Agonist activity of LSD and lisuride at cloned $5 \mathrm{HT}_{2 \mathrm{~A}}$ and $5 \mathrm{HT}_{2 \mathrm{C}}$ receptors. Psychopharmacology 136:409-414

Egan C, Grinde E, Dupre A, Roth BL, Hake M, Teitler M, Herrick-Davis K (2000) Agonist high and low state ratios predict drug intrinsic activity and a revised ternary complex mechanism at serotonin $5-\mathrm{HT}_{2 \mathrm{~A}}$ and $5-\mathrm{HT}_{2 \mathrm{C}}$ receptors. Synapse 35:144-150

Fiorella D, Rabin RA, Winter JC (1995a) The role of the 5-HT $2 \mathrm{~A}$ and 5$\mathrm{HT}_{2 \mathrm{C}}$ receptors in the stimulus effects of hallucinogenic drugs I: antagonist correlation analysis. Psychopharmacology 121:347356

Fiorella D, Rabin RA, Winter JC (1995b) Role of 5-HT2A and 5HT2C receptors in the stimulus effects of hallucinogenic drugs. II: reassessment of LSD false positives. Psychopharmacology 121:357-363

Fitzgerald LW, Conklin DS, Krause CM, Marshall AP, Patterson JP, Tran DP, Iyer G, Kostich WA, Largent BL, Hartig PR (1999) High-affinity agonist binding correlates with efficacy (intrinsic activity) at the human serotonin $5-\mathrm{HT}_{2 \mathrm{~A}}$ and $5-\mathrm{HT}_{2 \mathrm{C}}$ receptors: evidence favoring the ternary complex and two-state models of agonist action. J Neurochem 72:2127-2134
Garcia EE, Smith RL, Sanders-Bush E (2007) Role of Gq protein in behavioral effects of the hallucinogenic drug 1-(2, 5-dimethoxy-4iodophenyl)-2-aminopropane. Neuropharmacology 52:1671-1677

Gerber R, Barbaz BJ, Martin LL, Neale R, Williams M, Liebman JF (1985) Antagonism of L-5-hydroxytryptophan-induced headtwitching in rats by lisuride: a mixed 5-hydroxytryptamine agonist-antagonist? Neurosci Lett 60:207-213

Geyer MA, Vollenweider FX (2008) Serotonin research: contributions to understanding psychoses. Trends Pharmacol Sci 29:445-453

Gillin JC, Pulvirenti L, Withers N, Golshan S, Koob G (1994) The effects of lisuride on mood and sleep during acute withdrawal in stimulant abusers: a preliminary report. Biol Psychiatry 35:843-849

Glennon RA (1990) Do classical hallucinogens act as 5-HT 2 agonists or antagonists? Neuropsychopharmacology 3:509-517

Glennon RA (1991) Discriminative stimulus properties of hallucinogens and related designer drugs. NIDA Res Monogr 116:25-44

Glennon RA, Hauck AE (1985) Mechanistic studies on DOM as a discriminative stimulus. Pharmacol Biochem Behav 23:937941

Glennon RA, Titeler M, McKenney JD (1984) Evidence for 5- $\mathrm{HT}_{2}$ involvement in the mechanisms of action of hallucinogenic agents. Life Sci 35:2505-2511

González-Maeso J, Yuen T, Ebersole BJ, Wurmbach E, Lira A, Zhou M, Weisstaub N, Hen R, Gingrich JA, Sealfon SC (2003) Transcriptome fingerprints distinguish hallucinogenic and nonhallucinogenic 5-hydroxytryptamine $2 \mathrm{~A}$ receptor agonist effects in mouse somatosensory cortex. J Neurosci 23:8836-8843

González-Maeso J, Weisstaub NV, Zhou M, Chan P, Ivic L, Ang R, Lira A, Bradley-Moore M, Ge Y, Zhou Q, Sealfon SC, Gingrich JA (2007) Hallucinogens recruit specific cortical 5- $\mathrm{HT}_{2 \mathrm{~A}}$ receptor-mediated signaling pathways to affect behavior. Neuron 53:439-452

Gopinathan G, Teräväinen H, Dambrosia JM, Ward CD, Sanes JN, Stuart WK, Evarts EV, Calne DB (1981) Lisuride in parkinsonism. Neurology 31:371-376

Greiner T, Burch NR, Edelberg R (1958) Psychopathology and psychophysiology of minimal LSD-25 dosage; a preliminary dosage-response spectrum. AMA Arch Neurol Psychiatry 79:208-210

Halberstadt AL, Buell MR, Masten VL, Risbrough VB, Geyer MA (2008) Modification of the effects of 5-methoxy-N, Ndimethyltryptamine on exploratory behavior in rats by monoamine oxidase inhibitors. Psychopharmacology 201:55-66

Halberstadt AL, van der Heijden I, Ruderman MA, Risbrough VB, Gingrich JA, Geyer MA, Powell SB (2009) $5-\mathrm{HT}_{2 \mathrm{~A}}$ and $5-\mathrm{HT}_{2 \mathrm{C}}$ receptors exert opposing effects on locomotor activity in mice. Neuropsychopharmacology 34:1958-1967

Herrmann WM, Horowski R, Dannehl K, Kramer U, Lurati K (1977) Clinical effectiveness of lisuride hydrogen maleate: a doubleblind trial versus methysergide. Headache 17:54-60

Holohean AM, White FJ, Appel JB (1982) Dopaminergic and serotonergic mediation of the discriminable effects of ergot alkaloids. Eur J Pharmacol 81:595-602

Jacobs BL, Trulson ME, Stern WC (1977) Behavioral effects of LSD in the cats: proposal of an animal behavioral model for studying the actions of hallucinogenic drugs. Brain Res 132:301-314

Johansson C, Jackson DM, Zhang J, Svensson L (1995) Prepulse inhibition of acoustic startle, a measure of sensorimotor gating: effects of antipsychotics and other agents in rats. Pharmacol Biochem Behav 52:649-654

Kenakin T (1995) Agonist-receptor efficacy. II. Agonist trafficking of receptor signals. Trends Pharmacol Sci 16:232-238

Kimura KK, Akai TT, Nakamura KK, Yamaguchi MM, Nakagawa H, Oshino NN (1991) Dual activation by lisuride of central serotonin 5- $\mathrm{HT}_{1 \mathrm{~A}}$ and dopamine $\mathrm{D}_{2}$ receptor sites: drug discrimination and receptor binding studies. Behav Pharmacol 2:105-112 
Krebs-Thomson K, Paulus MP, Geyer MA (1998) Effects of hallucinogens on locomotor and investigatory activity and patterns: influence of $5-\mathrm{HT}_{2 \mathrm{~A}}$ and $5-\mathrm{HT}_{2 \mathrm{C}}$ receptors. Neuropsychopharmacology 18:339-351

Kuhn DM, White FJ, Appel JB (1978) The discriminative stimulus properties of LSD: mechanisms of action. Neuropharmacology $17: 257-263$

Kurrasch-Orbaugh DM, Watts VJ, Barker EL, Nichols DE (2003) Serotonin 5-hydroxytryptamine $2 \mathrm{~A}$ receptor-coupled phospholipase $\mathrm{C}$ and phospholipase $\mathrm{A}_{2}$ signaling pathways have different receptor reserves. J Pharrmacol Exp Ther 304:229-237

Leysen JE (1989) Use of 5-HT receptor agonists and antagonists for the characterization of their respective receptor sites. In: Boulton AA, Baker GB, Butterworth $\mathrm{R}$ (eds) Drugs as tools in neurotransmitter research. Neuromethods, vol 12. Springer, Berlin, pp 299-350

Lieberman A, Goldstein M, Neophytides A, Kupersmith M, Leibowitz M, Zasorin N, Walker R, Kleinberg D (1981) Lisuride in Parkinson disease: efficacy of lisuride compared to levodopa. Neurology 31:961-965

Lieberman AN, Gopinathan G, Neophytides A, Leibowitz M, Walker R, Hiesiger E (1983) Bromocriptine and lisuride in Parkinson disease. Ann Neurol 13:44-47

Liuzzi A, Chiodini PG, Oppizzi G, Botalla L, Verde G, De Stefano L, Colussi G, Gräf KJ, Horowski R (1978) Lisuride hydrogen maleate: evidence for a long lasting dopaminergic activity in humans. J Clin Endocrinol Metab 46:196-202

Mansbach RS, Geyer MA, Braff DL (1988) Dopaminergic stimulation disrupts sensorimotor gating in the rat. Psychopharmacology 94:507-514

Marini JL, Jacobs BL, Sheard MH, Trulson ME (1981) Activity of a nonhallucinogenic ergoline derivative, lisuride, in an animal behavior model for hallucinogens. Psychopharmacology 73:328-331

Marona-Lewicka D, Kurrasch-Orbaugh DM, Selken JR, Cumbay MG, Lisnicchia JG, Nichols DE (2002) Re-evaluation of lisuride pharmacology: 5-hydroxytryptamine ${ }_{1 \mathrm{~A}}$ receptor-mediated behavioral effects overlap its other properties in rats. Psychopharmacology 164:93-107

Marona-Lewicka D, Chemel BR, Nichols DE (2009) Dopamine D4 receptor involvement in the discriminative stimulus effects in rats of LSD, but not the phenethylamine hallucinogen DOI. Psychopharmacology 203:265-277

McCall RB, Aghajanian GK (1980) Hallucinogens potentiate responses to serotonin and norepinephrine in the facial motor nucleus. Life Sci 26:1149-1156

Millan MJ, Maiofiss L, Cussac D, Audinot V, Boutin JA, Newman-Tancredi A (2002) Differential actions of antiparkinson agents at multiple classes of monoaminergic receptor. I. A multivariate analysis of the binding properties of 14 drugs at 21 native and cloned human receptor subtypes. J Pharmacol Exp Ther 303:791-804

Newman-Tancredi A, Cussac D, Audinot V, Nicolas JP, De Ceuninck F, Boutin JA, Millan MJ (2002a) Differential actions of antiparkinson agents at multiple classes of monoaminergic receptor. II. Agonist and antagonist properties at subtypes of dopamine $\mathrm{D}_{2}$-like receptor and alpha $1 / \mathrm{alpha}_{2}$-adrenoceptor. J Pharmacol Exp Ther 303:805-814

Newman-Tancredi A, Cussac D, Quentric Y, Touzard M, Verrièle L, Carpentier N, Millan MJ (2002b) Differential actions of antiparkinson agents at multiple classes of monoaminergic receptor. III. Agonist and antagonist properties at serotonin, 5- $\mathrm{HT}_{1}$ and $5-\mathrm{HT}_{2}$, receptor subtypes. J Pharmacol Exp Ther 303:815-822

Nichols DE, Nichols CD (2008) Serotonin receptors. Chem Rev 108:1614-1641

Nichols DE, Frescas S, Marona-Lewicka D, Kurrasch-Orbaugh DM (2002) Lysergamides of isomeric 2, 4-dimethylazetidines map the binding orientation of the diethylamide moiety in the potent hallucinogenic agent $\mathrm{N}, \mathrm{N}$-diethyllysergamide (LSD). J Med Chem 45:4344-4349

Ouagazzal A, Grottick AJ, Moreau J, Higgins GA (2001) Effect of LSD on prepulse inhibition and spontaneous behavior in the rat. A pharmacological analysis and comparison between two rat strains. Neuropsychopharmacology 25:565-575

Parkes JD, Schachter M, Marsden CD, Smith B, Wilson A (1981) Lisuride in parkinsonism. Ann Neurol 9:48-52

Piercey MF, Hoffmann WE, Smith MW, Hyslop DK (1996) Inhibition of dopamine neuron firing by pramipexole, a dopamine $\mathrm{D}_{3}$ receptor-preferring agonist: comparison to other dopamine receptor agonists. Eur J Pharmacol 312:35-44

Pieri M, Schaffner R, Pieri L, Da Prada M, Haefely W (1978) Turning in MFB-lesioned rats and antagonism of neuroleptic-induced catalepsy after lisuride and LSD. Life Sci 22:1615-1622

Rabin RA, Regina M, Doat M, Winter JC (2002) 5- $\mathrm{HT}_{2 \mathrm{~A}}$ receptorstimulated phosphoinositide hydrolysis in the stimulus effects of hallucinogens. Pharmacol Biochem Behav 72:29-37

Raffaelli E Jr, Martins OJ, dos Santos P, Dãgua Filho A (1983) Lisuride in cluster headache. Headache 23:117-121

Sadzot B, Baraban JM, Glennon RA, Lyon RA, Leonhardt S, Jan C-R, Titeler M (1989) Hallucinogenic drug interactions at human brains $5-\mathrm{HT}_{2}$ receptor: implications for treating LSD-induced hallucinogenesis. Psychopharmacology 98:495-499

Sanders-Bush E (1994) Neurochemical evidence that hallucinogenic drugs are $5-\mathrm{HT}_{1 \mathrm{C}}$ receptor agonists: what next? NIDA Res Monogr 146:203-213

Schachter M, Blackstock J, Dick JP, George RJ, Marsden CD, Parkes JD (1979) Lisuride in Parkinson's disease. Lancet 2(8152):1129

Schmidt LG, Kuhn S, Smolka M, Schmidt K, Rommelspacher H (2002) Lisuride, a dopamine D2 receptor agonist, and anticraving drug expectancy as modifiers of relapse in alcohol dependence. Prog Neuropsychopharmacol Biol Psychiatry 26:209-217

Schreiber R, Brocco M, Millan MJ (1994) Blockade of the discriminative stimulus effect of DOI by MDL 100, 907 and the 'atypical' antipsychotics, clozapine and risperidone. Eur J Pharmacol 264:99-102

Schreiber R, Brocco M, Audinot V, Gobert A, Veiga S, Millan MJ (1995) (1-(2, 5-Dimethoxy-4 iodophenyl)-2-aminopropane)-induced headtwitches in the rat are mediated by 5-hydroxytryptamine (5-HT) $2 \mathrm{~A}$ receptors: modulation by novel $5-\mathrm{HT} 2 \mathrm{~A} / 2 \mathrm{C}$ antagonists, D1 antagonists and 5-HT1A agonists. J Pharmacol Exp Ther 273: $101-112$

Sipes TE, Geyer MA (1994) Multiple serotonin receptor subtypes modulate prepulse inhibition of the startle response in rats. Neuropharmacology 33:441-448

Sipes TE, Geyer MA (1995a) 8-OH-DPAT disruption of prepulse inhibition in rats: reversal with (+)WAY 100, 135 and localization of site of action. Psychopharmacology 117:41-48

Sipes TE, Geyer MA (1995b) DOI disruption of prepulse inhibition of startle in the rat is mediated by $5-\mathrm{HT}_{2 \mathrm{~A}}$ and not by $5-\mathrm{HT}_{2 \mathrm{C}}$ receptors. Behav Pharmacol 6:839-842

Somerville BW, Herrmann WM (1978) Migraine prophylaxis with Lisuride hydrogen maleate - a double blind study of Lisuride versus placebo. Headache 18:75-79

Stoll WA (1949) Ein neues, in sehr kleinen mengen wirksames phantastikum. Schweiz Arch neurol 64:483-484

Titeler M, Lyon RA, Glennon RA (1988) Radioligand binding evidence implicates the brain $5-\mathrm{HT}_{2}$ receptor as a site of action for LSD and phenylisopropylamine hallucinogens. Psychopharmacology 94:213-216

Vaamonde J, Luquin MR, Obeso JA (1991) Subcutaneous lisuride infusion in Parkinson's disease. Response to chronic administration in 34 patients. Brain 114(Pt 1B):601-617 
Vance ML, Evans WS, Thorner MO (1984) Drugs five years later. Bromocriptine. Ann Intern Med 100:78-91

Verde G, Chiodini PG, Liuzzi A, Cozzi R, Favales F, Botalla L, Spelta B, Dalla Bonzana D, Rainer E, Horowski R (1980) Effectiveness of the dopamine agonist lisuride in the treatment of acromegaly and pathological hyperprolactinemic states. J Endocrinol Invest 3:405-414

Vickers SP, Easton N, Malcolm CS, Allen NH, Porter RH, Bickerdike MJ, Kennett GA (2001) Modulation of 5- $\mathrm{HT}_{2 \mathrm{~A}}$ receptormediated head-twitch behaviour in the rat by $5-\mathrm{HT}_{2 \mathrm{C}}$ receptor agonists. Pharmacol Biochem Behav 69:643-652

Vollenweider FX, Vollenweider-Scherpenhuyzen MFI, Bäbler A, Vogel H, Hell D (1998) Psilocybin induces schizophrenia-like psychosis in humans via a serotonin-2 agonist action. NeuroReport 9:3897-3902

Vollenweider FX, Csomor PA, Knappe B, Geyer MA, Quednow BB (2007) The effects of the preferential 5-HT2A agonist psilocybin on prepulse inhibition of startle in healthy human volunteers depend on interstimulus interval. Neuropsychopharmacology 32:1876-1887
Watts VJ, Lawler CP, Rox DR, Neve KA, Nichols DE, Mailman RB (1995) LSD and structural analogs: pharmacological evaluation at $\mathrm{D}_{1}$ dopamine receptors. Psychopharmacology 118:401409

White FJ, Appel JB (1982) Lysergic acid diethylamide (LSD) and lisuride: differentiation of their neuropharmacological actions. Science 216:535-537

White FJ, Wang RY (1983) Comparison of the effects of LSD and lisuride on A10 dopamine neurons in the rat. Neuropharmacology 22:669-676

White FJ, Wang RY (1984) Pharmacological characterization of dopamine autoreceptors in the rat ventral tegmental area: microiontophoretic studies. J Pharmacol Exp Ther 231:275-280

White FJ, Holohean AM, Appel JB (1981) Lack of specificity of an animal behavior model for hallucinogenic drug action. Pharmacol Biochem Behav 14:330-343

Yamaguchi M, Kimura-Iwasaki K, Akai T, Nakada Y, Nakagawa H (1991) Terguride, a dopamine $\mathrm{D}(2)$ partial agonist, as a discriminative stimulus in rats. Behav Pharmacol 2:233-240 